\title{
The Myth of Bankability
}

Definition and Management in the Context of Photovoltaic Project Financing in Germany

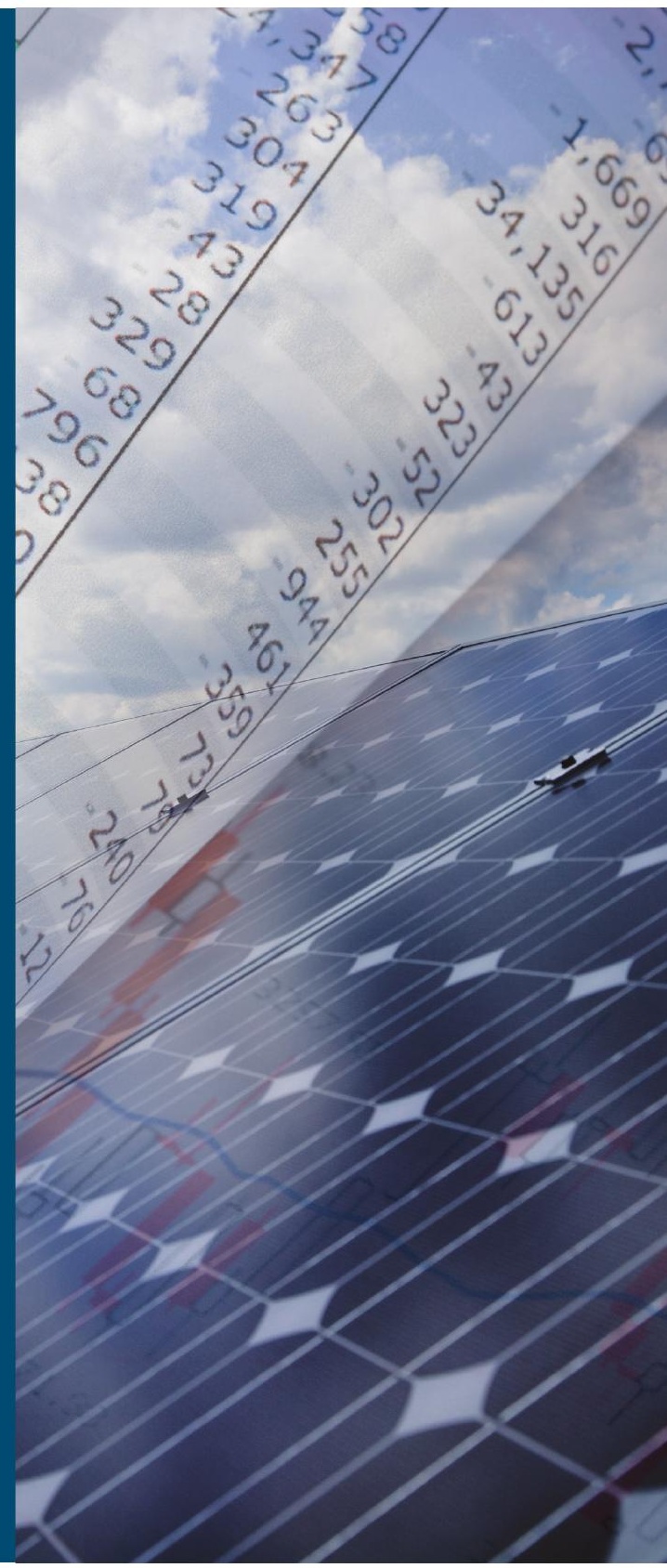




\section{Authors}

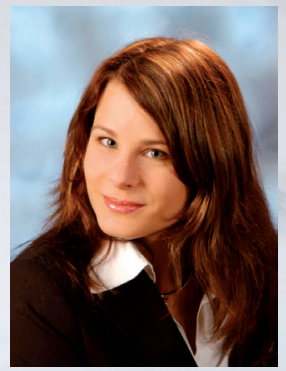

Nina Hampl,

Institute for Economy and

the Environment, University

of St. Gallen, Switzerland

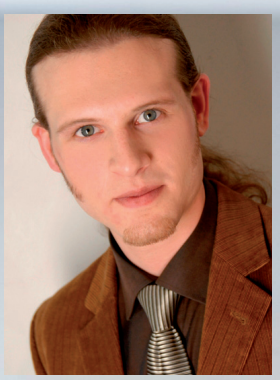

Florian Lüdeke-Freund,

Centre for Sustainability

Management, Leuphana

University of Lüneburg, Germany
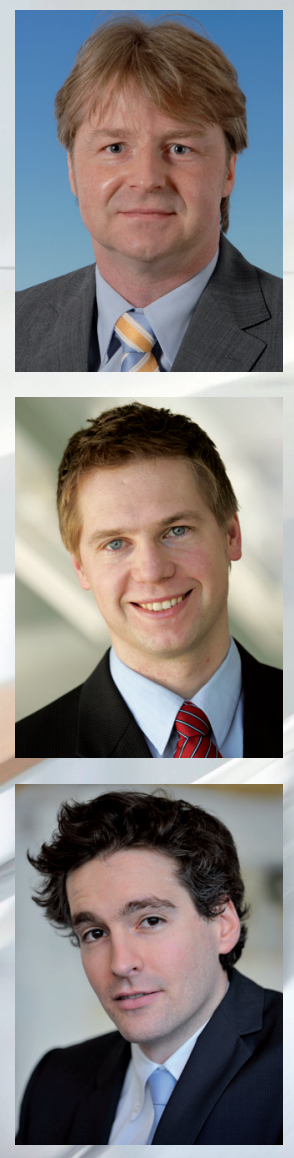

Dr. Christoph Flink,

Nordic International

Management Institute,

Chengdu, China

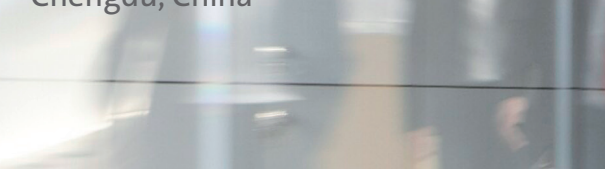

Sebastian Olbert,

goetzpartners Management

Consultants,

Munich, Germany

Valentin Ade,

COLEXON Energy AG,

Hamburg, Germany

\section{Content}

\section{Executive Summary}

1. Introduction

1.1 Study background

1.2 Market overview

2. Bankability - From Myth to Management

2.1 Towards a definition of bankability

2.2 Bankability from a multi-stakeholder perspective

2.3 Project bankability from a bank's perspective

3. Conclusions and Recommendations for Future Action

Table of Figures

About goetzpartners/About COLEXON

Contact

Disclaimer

goetzpartners \& COLEXON (eds.) (2011): Hampl, N.; Lüdeke-Freund, F.; Flink, C.; Olbert, S. \& Ade, V. (authors): The Myth of Bankability - Definition and Management in the Context of Photovoltaic Project Financing in Germany. 


\section{Executive Summary}

\section{Germany is the lead market for the global PV industry}

During the past years, Germany witnessed a remarkable boom in solar photovoltaic (PV) installations. Favorable regulatory frameworks as well as a maturing global PV industry, offering continuously lower prices, were just two of the main drivers leading to the industry's expansion. Though, an increasing inflow of capital was another necessary factor for this development. Monitoring the new capacity installations in Germany reveals a high confidence level of investors and financial institutions in the industry's financial opportunities, as the financial crisis and the following economic downturn did not lead to a significant slowdown in total PV installations. Although being a rooftop market mainly, Germany also accounts for the most ground-mounted megawatt installations globally with $1.4 \mathrm{GW}$ of newly installed capacity in 2010.

\section{Bankability receives increased attention}

Nonetheless, the financial crisis has also left its mark. In 2008 and 2009 credit markets were mainly dried up, due to the collapse of some major financial institutions. Liquidity in the financial markets, at that time, had become a major issue for large-scale PV projects. As a consequence of the credit crunch, banks needed to recondition their lending criteria and the assessment process for project finance became stricter. Banks began to "cherry-pick" projects of outstanding quality and as a result the bankability of projects, project components and stakeholders received increasing attention.

\section{Bankability is perceived and managed differently among stakeholders}

The various players in this market seem to agree on the importance of bankability and the term started to be used widely. However, there is no common understanding of its meaning. While banks typically emphasize the impact of stable cash flows on the project's long-term debt service, equity investors tend to focus on their expectations on investment returns, possible tax incentives and their portfolio strategies. Yet, to ensure a project's soundness, diligence in legal, technical and economic matters is imperative for both stakeholders. Therefore, PV project initiators, in cooperation with all other project stakeholders, need to communicate the right "bankability signals" to banks. Project developers, for instance, follow various approaches to manage their bankability. This includes road shows, bankability "scouts", and other promotional activities. Their strategy is to develop attractive projects in partnership with both banks and investors, aiming to contribute to their own portfolio and their project track record. Moreover, service providers, such as technical auditors, test and certification organizations take another crucial part in the development of projects and their financing process. These organizations set and enforce certain standards, which are gating for particular PV technologies and the projects 
themselves. All in all, the understanding of bankability is a complex one. Many players with different interests and strategies are engaged to actively manage bankability issues.

Mastering the bankability hurdle as of today offers no longer a competitive advantage

Due to their central role in both the initial investment and a project's cash flow, PV modules are the most crucial technical components of a PV project and therefore receive significantly more attention in the planning process than inverters and balance-of-system (BOS) components. At the same time, PV module markets are becoming increasingly internationalized and their value chain seems to shift towards the Chinese Mainland. This trend is not only driven by advantages in the local cost structure and by economy of scale effects, but also by an increasing management focus of the main Chinese players on the internationalization of their distribution channels. Participating in this market through selling their own brands, more and more Chinese companies have learned to overcome the bankability hurdle. As such, the available bankable module production capacity exceeds module demand. As such bankability is turning into an industry standard and PV modules are becoming commodity. Competing on eye-level, Chinese Tier 1 and other established module makers, today, are seeking differentiation to secure future sales and to even further increase their margins.

\section{Active bankability management is essential for differentiation and further growth}

Examining the understanding of bankability from various stakeholders' perspectives reveals that bankability is more than "pure philosophy". Instead, our study suggests that bankability ought to be actively managed, strategically as well as operationally. Active management of bankability means an active management of project risks, as much as their perceptions. Banks seek to manage bankability in order to reduce their credit risks, while equity investors are trying to secure adequate levels of return on their investments. Project developers and module producers, on the other hand, need to manage bankability as it is essential for them to build up market reputation and to control pricing especially in an overcapacity market. Finally, various service providers have emerged supporting the management of bankability through offering i.a. module performance insurances and module performance tests, which are particularly developed or customized to meet the needs of the PV project industry.

All in all, managing bankability is closely related to the concept of managing quality - and today quality is managed actively with high attention given by companies' top management, as it serves as a key differentiation factor in global competition across many industries. The PV industry is well-advised to apply such concepts to the crucial issue of achieving bankability for projects. The following report outlines promising approaches for doing so. 


\section{Introduction}

\subsection{Study background}

In-depth expert interviews in Germany and China

Next to the authors' market insights and project experience, the publication at hand builds on a qualitative research study conducted between September 2010 and January 2011, comprising over 20 in-depth expert interviews in Germany and China. Interviewees were stakeholders from five different categories: equity investors, project developers, service providers, module manufacturers and banks (see also Figure 1). The aim of this study was twofold: (1) to learn more about the criteria that debt capital providers and equity investors use for their investment decision-making, while focusing on qualitative aspects and trade-offs between decision criteria; (2) to increase our understanding about the meaning of bankability as a major investment criterion with distinct qualitative characteristics.

\section{Importance of qualitative aspects revealed in prior study}

This research project is also based on a quantitative analysis of lending criteria preferences. Approximately forty German PV financing experts assessed a predefined set of lending criteria in a joint study conducted by the Institute for Economy and the Environment at the University of St. Gallen and the Centre for Sustainability Management at the Leuphana University of Lüneburg in 2010.' The results indicate that, under specific circumstances, the brand and quality of PV modules can be more important in a bank's decision to finance a certain PV project than factors such as the debt service cover ratio (DSCR) or the equity ratio. The study gives rise for further research as it highlights the importance of qualitative aspects in PV project financing and emphasizes the need for a systematic analysis of bankability, especially of highly capital intensive PV projects.

\section{First report fully dedicated to bankability}

To our best knowledge, this is the first publication that is fully dedicated to a comprehensive understanding of bankability in the PV industry applying a multi-stakeholder and multidimensional perspective. The following chapter will provide a brief overview on past and current PV market developments, including the PV project finance market. The remainder of this report is specifically devoted to a definition of bankability and to the different stakeholder perspectives on bankability in PV project finance. The report concludes with the need for an active management of bankability and provides recommendations for further actions.

Lüdeke-Freund, F. \& Loock, M. (2011): Debt for Brands: Tracking Down a Bias in Financing Photovoltaic Projects in Germany, Journal of Cleaner Production, Vol. 19, No. 12, 1356-1364
(Lüdeke-Freund, F.; Hampl, N. \& Flink, C. (forthcoming): Bankability von Photovoltaik-Projekten, in: Böttcher, J. (ed.): Solarvorhaben - Wirtschaftliche, technische und rechtliche Aspekte, Munich: Oldenbourg.) 


\section{Figure 2: Annual PV installations globally and in Germany [GW p.a.]}

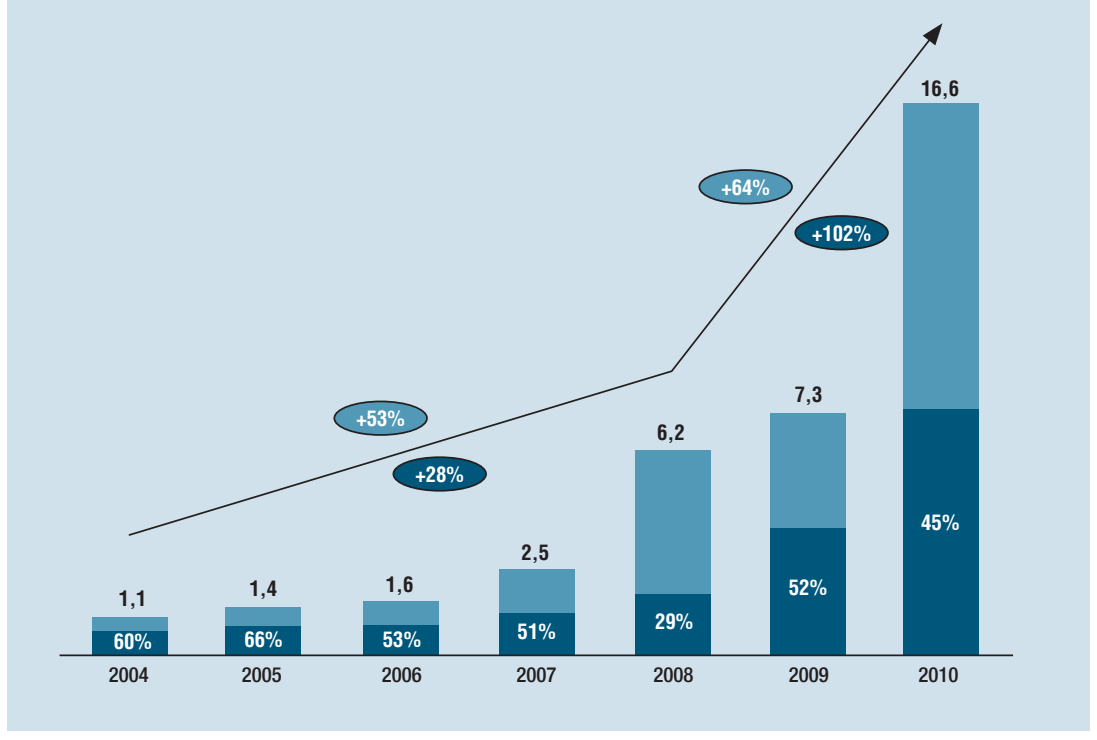

- \% CAGR - Global

- \% CAGR - Germany

(goetzpartners)

\subsection{Market overview}

\section{Germany as the front-runner in the global PV industry}

Over the past few years, the global PV industry has experienced an astonishing growth path. The Global Trends in Sustainable Energy Investment 2010 report shows a cumulative average growth rate of about $100 \%$ for new solar investments from 2004 to 2009, including the complete spectrum of solar technologies. ${ }^{2}$ Overall the global PV market witnessed sound growth, with annual rates for newly installed PV capacities of around $60 \%$ between 2004 and 2010. Despite its unfavorable energy yields of approximately 900 to $1050 \mathrm{kWh} / \mathrm{kWp}$ per annum, Germany turned out to be the main market driver, accounting for $50 \%$ of global PV demand on average since 2004 and showing tremendous annual growth with over $100 \%$ between 2008 and 2010 (see Figure 2). This "gold rush" was driven by a generous and reliable feet-in-tariff providing investment security for debt and equity providers. Despite efforts of the German government to slow down the growth of the German PV market through an unscheduled cut of the feed-in tariff in mid 2010, returns for investors were still attractive enough because of even further declining module prices. Thus, new PV installations were driven to an all time high of $7.4 \mathrm{GW}$ in 2009, with a rise of total cumulative capacity from $9.8 \mathrm{GW}$ in 2009 to $17.3 \mathrm{GW}$ in 2010 .

With over $80 \%$ of all systems in 2010 being installed on roofs, the German market is principally a rooftop market. Nonetheless, with $1.4 \mathrm{GW}$ installed capacity in the ground-mounted PV sector in 2010 (i.e. 19\% of the total market), the German market is as well best suited to learn from in the megawatt capacity class; for comparison, megawatt installations in Germany equal the total new installations of the two main future growth markets, North America and China together. For this reason, Germany is the most mature PV market with by far the most experienced market participants even for ground-mounted megawatt installations.

\section{The PV "gold rush" is over}

The German feed-in tariff has been a role model for other national governments, especially in Europe. Country-specific PV policies and the paradigm shift in the European energy landscape helped Europe to become the leading PV region globally with a market share of over $70 \%$ in 2010. Though, observing the current market situation there are clear signs that the PV "gold rush" is over. In Q1/2011 PV module shipments declined relative to the previous quarter for the first time since the beginning of 2009; but this 
time the signs for a fast market recovery are not evident. The PV industry is facing the impact of a market shift from a sellers to a buyers market with eroding margins for component suppliers. In early 2009 prices came under pressure for the first time, as they are still today. For ground-mounted projects, prices for "bankable" modules are already below 1 EUR/W. This development is mainly influenced by the abrupt halt of the demand in the booming Italian market, which was caused by the uncertainties related to Italy's new feed-in tariff and the weakened demand in Germany in the first half of 2011. As the expected 2011 midyear cut in the feed-in tariff was not realized, Germany will see another half-year of strong PV demand resulting in approximately $5.5 \mathrm{GW}$ of newly installed capacity. But with its planned cut in 2012, it is anticipated that the German market will significantly shrink to a volume of approximately only $4 \mathrm{GW}$ per annum.

\section{Policy interventions throughout Europe indicate market stagnation}

Like Italy, Germany and France, more and more governments throughout Europe currently review their feed-in tariff systems. As a result, most of them have decreased their feed-in tariffs. Due to this incentive shortage, Europe's market share will shrink to approximately $40 \%$ by 2015 (see Figure 3). The worst thing to happen, however, would be if governments follow the Spanish example. Overwhelmed by the exploding market with 2.5 GW of newly installed PV capacity in 2008, the Spanish government introduced a market cap at $500 \mathrm{MW}$ of annually installed capacities. At that time, it was unclear if the PV industry was entering a phase of moderate stagnation or if other markets would be able to compensate for the shortfall of the Spanish market. In retrospect, it became clear that the German market was able to over-compensate for this, reaching $3.8 \mathrm{GW}$ of new PV installations in 2009. The remaining question to estimate the future market size is if there is another "Germany" to compensate for the decline in demand of the traditional growth

\section{Figure 3: Global PV market demand development [GW p.a.]}

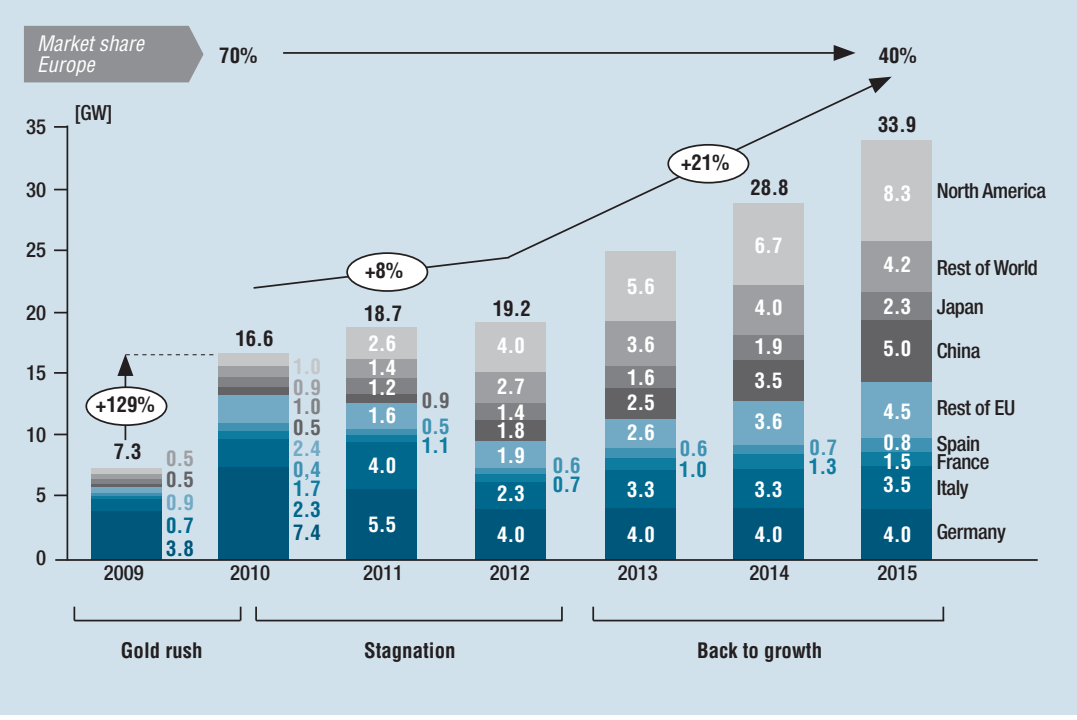

(goetzpartners)

In search for new, dynamic markets -

China and the US as future lead markets?

New global markets were emerging in 2010, leading to $16.6 \mathrm{GW}$ of worldwide newly installed PV capacity. As an example, the Italian market rose from $0.7 \mathrm{GW}$ in 2009 up to about $2.3 \mathrm{GW}$ of newly installed capacity in 2010, which was i.a. the result of a new policy that allowed municipalities to independently approve PV installations of up to $1 \mathrm{MW}$ in size. The resulting countless number of small parks of such size led to a review of Italy's 
support program in order to regain control over the market's development. Under the recently signed "Conto Energia 4" the feed-in tariff was significantly reduced and budget constraints for large-scale PV projects were established. For this reason, the Italian market is expected not to become a sufficient counterweight for the anticipated shortfall of the German market place.

As the global PV industry comprises a more diversified set of countries, big hopes are put on the Chinese and the US markets. Many believe that the USA may have the potential to be the future driver for PV demand, once the full potential of its strong solar irradiation and tremendous space is exploited. Such a development has already been expected since years, but the future development of the state-specific subsidies, feed-in tariffs and tax incentives are still uncertain. Today's incentive policies in the US are too fragmented and complex, and therefore unattractive for investors.

And what about China? Despite the fact that China is a worldwide leader in PV solar module production, there are reasonable doubts that China's government is determined to subsidize its domestic solar power generation on a large scale and that the target of $20 \mathrm{GW}$ by 2020 will be realized soon. ${ }^{3}$ In 2010, the Solar Roofs Program in eastern China and provincial-level feed-in tariffs contributed only little to China's totally installed solar power capacity of $800 \mathrm{MW}$. Tariffs awarded so far do not allow for a favorable return on investment. Most installations come from the Golden Sun Project and two solar concession rounds. Following the second solar concession round, 280 MW were put up for bid in 2010 alone. However, due to the fact that

\section{Figure 4: Global PV module supply demand imbalances [GW p.a.]}

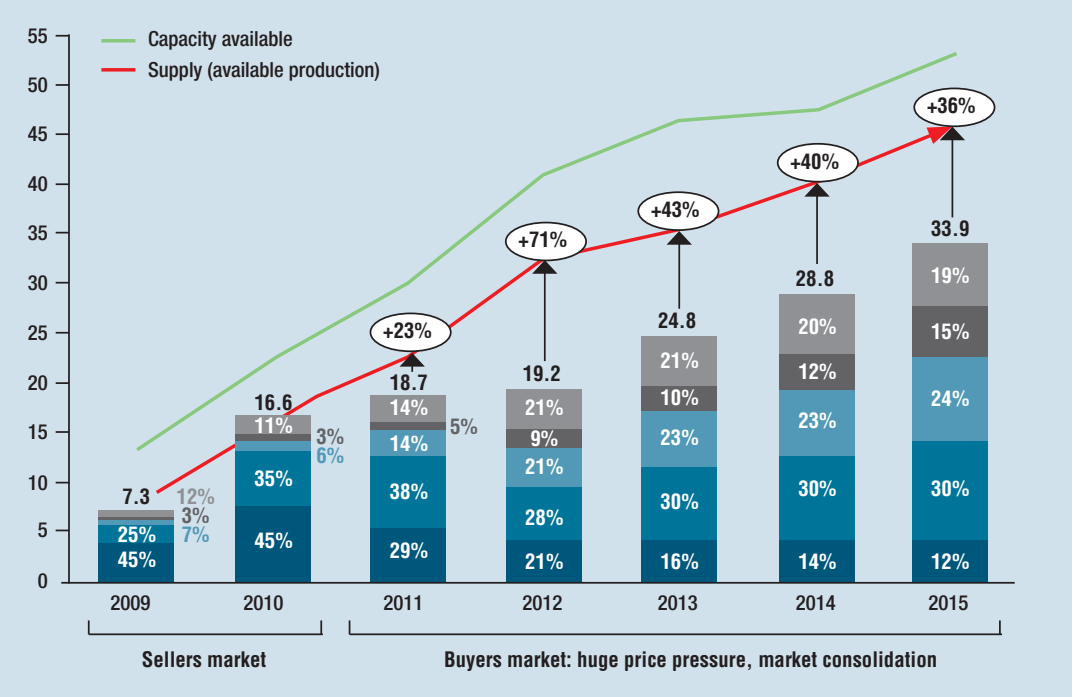

China's solar power project development is dominated by state-owned enterprises, which have the ability to forgo short-term profits for long-term gain, it is uncertain to what extent foreign component producers will be able to participate in this market.

The challenge: selling modules despite overstocks and survive the upcoming shake out Changing the perspective from the demand to the production side, current estimates of excess production of modules indicate overstocks and price pressure (see Figure 4). According to IMS Research, global PV module inventory levels have reached more than $10 \mathrm{GW}$ in the second quarter of 2011, the highest amount recorded to date. ${ }^{4}$ During the times of the "gold rush", manufacturers have significantly increased their production capacities along the entire PV supply chain. Especially, Asian module producers heavily invest in corporate assets and will account for around $40 \mathrm{GW}$ in produc- 
tion capacity by 2015, representing the epicenter of PV module production with $86 \%$ of the total market. In addition, contract manufacturers known from the semiconductor industry such as Flextronics, Jabil or Foxconn start to ramp up own production capacities, which will further increase competition and probably accelerate the price decline. As a consequence, the PV industry will face a phase of consolidation where the wheat gets separated from the chaff. goetzpartners estimates that approximately $40 \%$ of the global cell and module manufacturers will not survive the upcoming global shake out and will vanish from the market until $2015 .{ }^{5}$

\section{Bankability is the key to PV project financing - in 2009 PV projects absorbed \$24 billion worldwide}

Key to all newly installed PV capacity is to secure funding (see also Excursus 1). In 2009, $\$ 162$ billion were invested in renewable energies worldwide, of which project-based asset finance for new energy generation capacities totaled $\$ 101$ billion or $62 \%$ (see Figure 5 ). Wind and solar are by far the largest asset classes with $\$ 67$ and $\$ 24$ billion, respectively. While wind energy has become an established and mature industry with positive growth rates even during the latest economic downturn, the PV industry has moved into a very challenging situation. Investments in 2009 were significant, but were in fact $27 \%$ below the figures in 2008 - whereas this development relates to falling system costs and not decreasing capacity installations. In several energy outlooks PV is seen as one of the most important renewable energy technologies for future electricity production. Though, considering the development of the two former PV lead markets, Germany and Spain, as discussed above, reveals that this industry faces great challenges ahead.

\section{Figure 5: Global transactions in renewable} energies

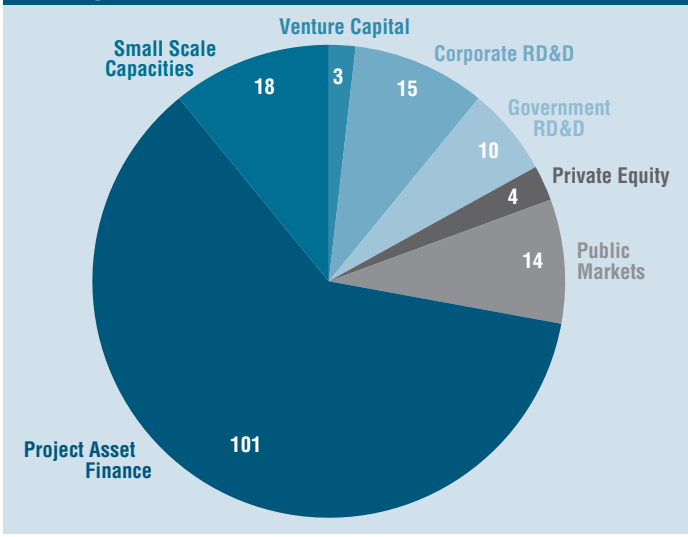

(United Nations Environment Programme (UNEP); Sustainable Energy Finance Initiative (SEFI) \& Bloomberg New Energy Finance (NEF) (2010): Global Trends in Sustainable Energy Investment 2010. Analysis of Trends and Issues in the Financing of Renewable Energy and Energy Efficiency, Paris and London 2010.) 


\section{Excursus 1: PV project financing}

Larger PV installations are typically set up as "projects" requiring special development and financing methods. While some years ago project financing was common for installations of a few hundred kWp, nowadays this method is only used for projects with capacities in the upper one-digit to three-digit MWp range. Project financing aims to acquire debt and equity capital. High debt-equity-ratios with a leverage effect of up to $80: 20$ are common. Consequently, evaluation through banks is gating for project financing. This is where project bankability comes into play. $\mathrm{PV}$ project bankability is a multidimensional criterion requiring a well-balanced set of management activities and goes beyond module supplier characteristics and module quality.

\section{Off-balance-financing creates challenges for banks}

The main purpose of PV project financing is the acquisition of large shares of debt capital. Three significant features characterize this financing method: off-balance-financing implies that financially-involved project parties separate the PV project from their own books by establishing a special purpose vehicle (SPV). Debt capital is taken onto the SPV's books. And, depending on the particular accounting standards, it therefore does not impact the accounting and balance sheet indicators of the parties involved in the project. Since a financial liquidation of a PV power plant is complicated and often less profitable, project cash flows alone have to guarantee for debt service and returns on equity (cash flow related lending). Lenders usually apply indicators, such as debt services, loan life and project life cover ratios to assess a project's ability to repay loans. Moreover, different degrees of recourse can be negotiated (full-, limited-, non-recourse lending), which can lead to higher credit costs and necessitates a broad risksharing among project parties.

\section{Conditions of PV project financing are changing}

The credit crunch with its peak in late 2008 changed the financial markets with their rules and related policies. Its impact on renewable energy project financing is twofold. On the one hand, this asset class continues to grow as it, based on political incentives, only indirectly depends on economical trends. Because of increasing liquidity costs, financing costs have increased. Yet, investment costs are decreasing as module prices are falling. On the other hand, projects with higher technical, legal, regulatory or other risks are being rescheduled. In addition, the nature of project initiators and financiers is shifting from pure financial investors to players like utilities. That is, the structure of project stakeholders will diversify. 


\section{Bankability - From Myth to Management}

\subsection{Towards a definition of bankability}

\section{Bankability as a multidimensional construct}

"Bankability" is one of the buzzwords in today's PV project finance markets. Even though its strong presence highlights its importance, actors in the PV industry do not share a common understanding of what bankability actually is or why one should address it. Definitions of bankability range from "pure philosophy" to a concept that needs to be taken seriously and be actively managed on strategic and operational levels. Bankability can be seen as a multidimensional construct based on legal, technical and economic project requirements. Moreover, bankability has different meanings and business impact for its various stakeholders. From a high-level perspective, bankability is a set of criteria independently defined by each bank or group of banks. Bank representatives consider bankability as an expression of trust in debt services and the achievement of secure returns. As a minimum, this trust requires predictable and stable cash flows over the entire financing period.

\section{The quantitative and qualitative dimension of bankability}

Banks typically evaluate projects from a risk perspective where they distinguish between different types of risks such as technological, regulatory and market risks. Following the process of risk identification, assessment and management, they aim at a minimum overall risk in order to secure loan repayments. In project finance, one of the most important risk measures for banks is DSCR, indicating the security of the loan repayment, i.e. the ability to fulfill the debt service on an annual basis. DSCR and related parameters are decisive economic "hard facts" that indicate the economic viability of a project and constitute the quantitative dimension of bankability. Furthermore, qualitative aspects such as the reputation of the project partners have as well an influence on the evaluation and decision-making process.

The following sections elaborate on the dimensions of bankability from the perspective of five different stakeholder groups: equity investors, project developers, service providers, module manufacturers and banks (see Figure 6). But overall, achieving bankability is about generating trust and transparency.
"For me, bankability is more like philosophy than business science. Because you cannot grasp it. It is quite differently valued by a large number of parties."

Head of Supply Chain Management,

Wholesaler/Project developer

\begin{abstract}
"At the end, it is about this: is the cash flow secure or not? A secure cash flow means secure from a legal, technical and economic perspective." Head of Competence Centre Renewable Energies, Major bank
\end{abstract}

\section{"Bankability means that the bank is convinced to the greatest possible extent that the cash flows are stable and the loan will be repaid." Credit Risk Manager, Structured Finance, Energy, Major bank}

\section{Figure 6: Bankability - Perspectives of different project stakeholders}

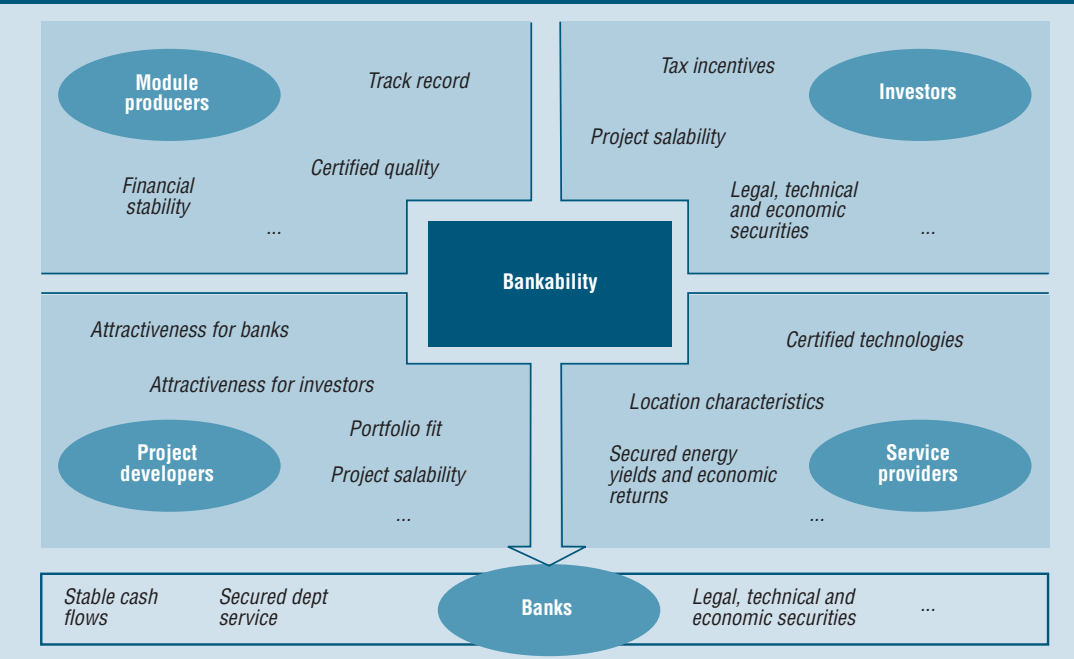

(Lüdeke-Freund, F. \& Olbert, S. (2011): Bankability: Definition - Bedeutung - Management, presentation 2nd St. Gallen Forum for Management of Renewable Energies, March 10/11, St. Gallen 2011. 


\title{
2.2 Bankability from a multi-stakeholder perspective
}

\author{
2.2.1 Equity investors
}

\section{Investors are attracted by mature projects}

At current market conditions, banks usually request an equity ratio between $15 \%$ and $30 \%$. Equity is either provided by the project initiator itself or a third party. Generally, those are project developers, utility companies, institutional investors, such as private equity funds or pension funds, or private investors like closed funds. Equity investors are typically attracted by mature projects with low risks, e.g. projects under late-stage construction, turnkey projects, and projects in operation from the "secondary market". Some investors, however, specifically invest in early project stages, proving that the actual project type and risk propensity depends on the investor's business model.

\section{Shortage in incentives and cost efficiency rather than funding}

In 2008 and 2009, at a time when financial markets were specifically hard hit by the credit crunch, financing was the most challenging factor for PV projects. Today, it seems there is a consensus among investors that for high-quality projects with a good set-up funding is not an issue - neither in debt nor in equity. Current critical issues are uncertainties related to the reliability of specific renewable energy policy frameworks and to the essential question if module prices will decline fast enough to match today's decreasing feed-in tariffs and still meet the expected return, i.e. pass the investor's hurdle rate. In other words, what we see today is rather a shortage in politically-induced incentives or cost efficiency than in funding.

\section{Investors see themselves as "secondary analysts"}

For equity investors, the bankability of PV projects is particularly of interest at the early stage of a project's development, as project rights can only be sold if projects are eligible for debt financing. Once bankability is achieved, and assuming that in general debt is less expensive than equity, debt availability determines the overall financing structure, i.e. the leverage, as well as the rate of return of a project. Equity investors typically see themselves as "secondary analysts" that base their assessments on other actors' data and documentation, e.g. banks. Aspects such as track record, experience and financial strength of project partners like project developers and engineering, procurement and construction (EPC) contractors, as well as con- 
fidence in the experience and the performance data of the technology are paramount for equity investors. Moreover, the predictability and stability of cash flows, the possibility to resell the project and to achieve capital gains and tax advantages are important investment criteria. Above all, the local legal environment needs to be as reliable as possible.

\section{Investors strive for long-term partnerships}

In order to manage "investability" and bankability of projects, equity investors typically search for long-term relationships with project partners such as project developers, EPC contractors and banks. These partnerships are based on trust and win-win-arrangements leading to regular deal flows and decreased transaction costs, e.g. for contracting. But as the investment patterns of equity providers turn more and more global, their today's partner of choice also needs to increase their international footprint in order to retain the business relationship long-term.

\subsubsection{Project developers}

\section{Project financing part of integrated business models}

Based on their position along the value chain and the degree of horizontal integration, project developers operate based on a variety of different business models. While some players integrate all stages of the value chain from module wholesale, through EPC activities, to operations and maintenance (O\&M), others limit their focus on technical project development and thus apply a general contractor business model. Project financing often is part of an integrated business model, which aims to develop (pre-) turnkey projects that are then sold to investors. Such a strategy is applied by the majority of the top 15 project developers in Germany. Their business model sometimes implies that project developers temporarily also act as equity investors. If the project developers are large enough they provide their own funds or use the credit lines provided by their banks. Otherwise, they need to enter into partnerships with other equity investors.

\section{Need to actively manage own bankability}

Project developers are major stakeholders of PV projects. They have a high impact and influence on a project's bankability through their selection of components and other project elements, and through their own bankability status. Our expert interviews revealed several characteristics, which were attributed to bankable project developers, but can also be applied to component producers and service providers. An overview is given in Table 1. 
Table 1: Dimensions of bankability criteria for market participants ${ }^{6}$

\begin{tabular}{|c|c|}
\hline Bankability dimensions & Exemplary criteria \\
\hline 1. Company profile & $\begin{array}{l}\text { Company size (e.g. revenue, market capitalization), } \\
\text { international footprint, value chain positioning } \\
\text { (upstream, downstream), legal structure, organization } \\
\text { and management structure, age of company }\end{array}$ \\
\hline 2. Financial strengths & $\begin{array}{l}\text { Financial key performance indicators (e.g. balance } \\
\text { sheet, profit and loss statement), provisions, shareholder } \\
\text { structure, investors, investments }\end{array}$ \\
\hline $\begin{array}{l}\text { 3. Production and product } \\
\text { technology }\end{array}$ & $\begin{array}{l}\text { Production sites, size and equipment used } \\
\text { (manufacturer, maintenance intervals), operating } \\
\text { material, production capacity and volumes, } \\
\text { utilization rates, quality and environmental } \\
\text { management, certificates, cost reduction potential, } \\
\text { supplier, vertical integration }\end{array}$ \\
\hline 4. Performance record & $\begin{array}{l}\text { Project portfolio, project track record/references, } \\
\text { implementation strength, production ramp-up } \\
\text { and efficiency }\end{array}$ \\
\hline 5. Sales and service & $\begin{array}{l}\text { Delivery reliability, claim rate and management } \\
\text { process, distribution network and channels, } \\
\text { product guarantees, liabilities, insurances }\end{array}$ \\
\hline 6. Perceived bankability & $\begin{array}{l}\text { Awareness, reputation, strength of brand, experience, } \\
\text { know-how, qualified staff, partnerships with banks, } \\
\text { investors }\end{array}$ \\
\hline
\end{tabular}

Amongst the characteristics most often mentioned were a convincing track record (project portfolio), size (e.g. in terms of revenue), financial soundness (balance sheet, profit and loss statement), integration along the industry value chain, partnerships with component manufacturers (especially with module suppliers), good relationships with banks and investors, liabilities and guarantees for modules, and performance ratio guarantees for installed PV power plants. This non-exclusive list points to the central challenge that project developers are confronted with - to develop PV projects that are accepted by both lenders and investors equally, and further contribute to their own track record.

\section{Bankability achieved by combining different strategies}

Rather less established project developers might apply different strategies to compensate for a missing track record. They can make efforts to build up good relationships with banks and investors and carefully select reference projects for their portfolios. Project developers sometimes finance reference projects in advance if they are not yet bankable. Moreover, exclusive partnerships with high-standing or specialized module suppliers can contribute to their positioning. A strategy that was frequently mentioned during the interviews and that equally applies to module suppliers and project developers is to start "bottom up" with residential installations, since project development and financing is less challenging and risky in this business field. Building a megawatt track record based on this bottom up approach takes time but pays off in the mid-term. Once project developers have positioned themselves in the megawatt class, further strategies can be applied. This can be, for instance, an original equipment manufacturer

6) Lüdeke-Freund, F.; Hampl, N. \& Flink, C. (forthcoming): Bankability von Photovoltaik-Projekten, in: Böttcher, J. (ed.): Solarvorhaben - Wirtschaftliche, technische und rechtliche Aspekte, Munich: Oldenbourg 
(OEM) strategy to roll out new PV modules exclusively. Once banks list those modules on their so-called "white lists" the project developers will be more flexible and less vulnerable to demand shortages or corresponding price fluctuations in the module market.

\subsubsection{Module producers}

\section{Bankability as a key strategic factor for module producers}

During the financial crisis, bankability has become a key strategic factor of growing importance for PV module manufacturers (see also Excursus 2). In order to develop an own brand, module manufacturers have to master the bankability hurdle. Therefore, their products, as well as the companies themselves, have to become acceptable to banks, as PV projects are only bankable if their components and component providers are bankable.

\section{Market newcomers face challenges to achieve bankability}

Meanwhile, the PV market has seen a dramatic increase in the number of new PV module manufacturers entering this presumably attractive sector. However, in particular Chinese newcomers have found it difficult to reach international business standards and acceptance on international markets. But also new players from Eastern Europe have difficulties to demonstrate the required track records of their products, a sufficiently long history of their companies or a large enough size of their balance sheets. The same is true for providers of new PV module technologies, like amorphous thinfilm or so-called CIGS/CTZSS modules; these companies, however, face the additional difficulty of proving the long-term reliability of their products.

\section{Bankability ensured competitiveness of established brands}

The impact of bankability on module sales depends on the market sector. While for residential customers a good quality-price ratio is of higher importance than the status of bankability, for most institutional investors and commercial customers, bankability has become gating. In both sectors, though, this development has led to a preference for choosing established module brands. With a few exceptions, these premium players used to be mainly non-Chinese companies, who provided the perception of a superior quality for a higher price. This way, the need for bankability ensured competitiveness of West-European and international brands against cheaper products from China and other low-cost production countries.

\section{Low-cost bankable products will increase competition}

Today, bankability is a necessary criterion for a product in the PV module market to be traded. This means that non-bankable products have difficulties to find buyers on the market even for a lower price. According to this logic, higher-priced bankable modules will always find buyers, as long as the demand for bankable modules is higher than the capacity of bankable 
modules, and as long as the price is still acceptable to the return expectations of investors. In analogy to the power market, one could say that a PV merit order has been created in the market with the price building module being the one that delivers the minimum acceptable return to investors by being bankable at the same time (see Figure 7).

However, this "bankability shield" as a criterion for successive sales for premium brands is about to break in mid-term. By leaving current bankability criteria unchanged, more and more low-cost module manufacturers with substantial production volumes will master the bankability hurdle. As the new bankable supply is by far greater then the expected demand, significant overstocks and increasing pressure on module prices will push the already intense competition even further.

\section{"Tightened" bankability as a future industry entry barrier}

Bankability, in its current form, will eventually become an industry standard and therefore not serving as an industry entry barrier any longer. Accordingly, the opportunity for differentiation through bankability is likely to disappear. Up until now, bankability has been driven by banks after the financial crisis to minimize their risks. In the near future it might be premium brands that will drive bankability. For them, one way to ensure a market position with higher prices, leveraged brand awareness and customer access is to jointly tighten bankability criteria to increase the bankability

\section{Figure 7: Merit order in PV industry - schematic}
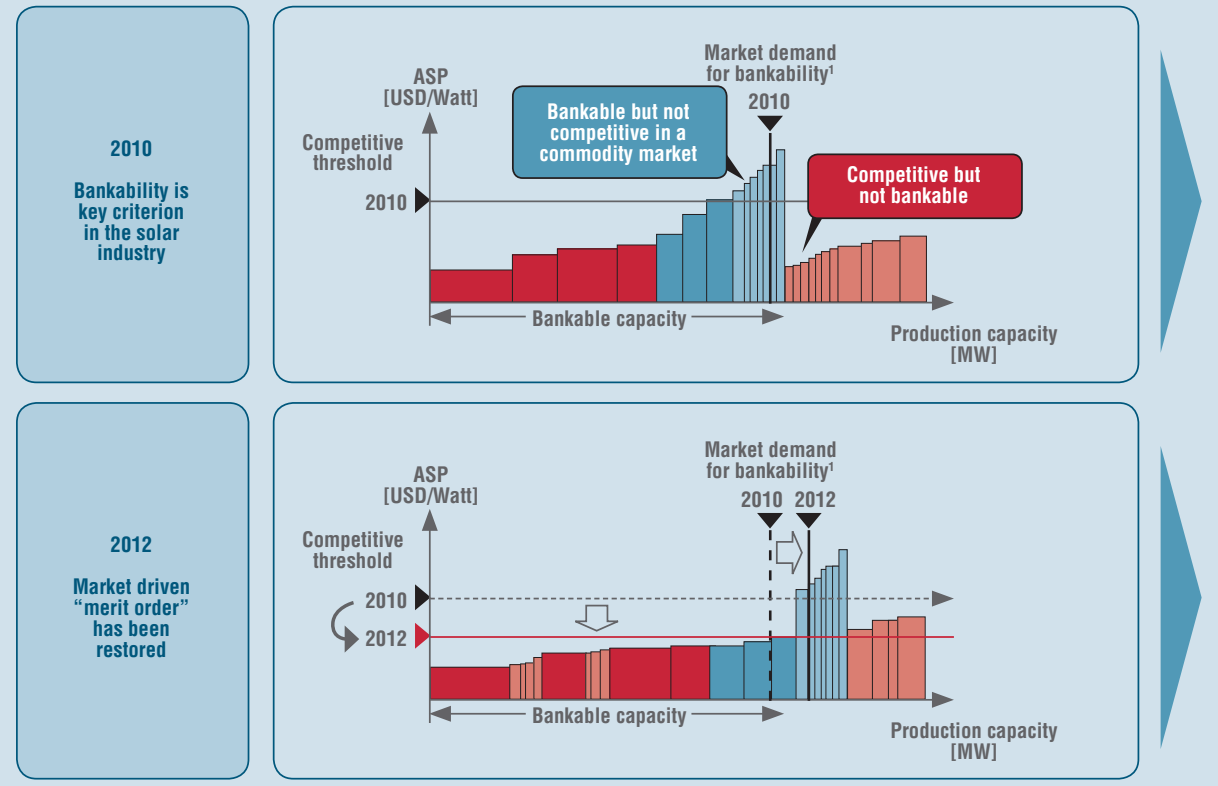

Bankability as a criterion for successive sales secures competitiveness of premium brands and represents a bankability shield towards upcoming Chinese playe

1] Bankability relevant for Europe, Japan and US markets; Source: goetzpartners 
hurdles and to maintain a price premium for "certified" superior quality. Certificates developed in close cooperation with technical institutes and service providers are one promising option to drive such an evolution of the PV market; roadshows for banks and investors are another. As such, bankability has to be managed actively, especially for premium brands.

Excursus 2: Module bankability and the strategy development path of Chinese module manufacturers

\section{Low-cost strategy to increase market share}

Up to recent years, Chinese module producers have put their main strategic attention on operational efficiency. Focusing on their lowcost manufacturing strength, they took advantage of cheap labor and energy costs, preferable land conditions, low capital costs, as well as relaxed environmental standards. They further developed their cost structure through increasing production capacities in order to realize economy of scale effects, investing in advanced processing methods to accomplish a competitive cost-quality ratio and developing vertical integration to cut down transfer costs along the supply chain. While foreign competitors, specifically in Europe, heavily invested in research and development to foster innovativeness, Chinese module manufacturer "juggernauts", like Yingli, Trina and Suntech, aimed at achieving lowest cost per watt. The strategy paid off and these Chinese players continuously gained market share.

\section{OEM strategy to indirectly achieve bankability}

Only lately has bankability progressively become a second strategic focus for some Chinese module OEMs. As Tier 3 module makers, their initial business model was contract manufacturing. They sold PV cells and modules primarily to German manufacturers or to project developers, thus, receiving "indirect bankability" of their products through those partners' well-established brands. However, in an attempt to achieve higher gross margins, they started to develop their own brands, and consequently faced the difficulty of becoming accepted and bankable on overseas markets.

\section{Background causes difficulties to achieve bankability}

In large-scale PV installations, module costs are still the largest part of the total project investment. Therefore, the selection of modules is a quite critical step in project development. Criteria applied comprise perceived product quality, track record of the module's performance in previous PV projects, product availability and on-time delivery, as well as the offer of after-sales services for the 25 years lifetime of the 
modules. Chinese companies had difficulties to fulfill these requirements due to various reasons. One was to place their products on the market, despite the negative connotation of "made in China" with "low quality". Additionally, they were not able to use the track records they have built up in the course of their OEM contracts. Moreover, customers had little trust in the companies' long-term survival and the Chinese legal system to execute the 25 years warranty industry standard.

\section{Addressing banks to actively manage bankability}

Chinese module producers applied different strategies to overcome these problems. Some companies specifically emphasized a partnering concept where they collaborate with highly reputed actors, e.g. project developers and EPCS, in order to increase trust in the quality of a project. It has been important for module manufacturers to cherry-pick their project partners. The less present a module manufacturer is in a certain country or region, the more important it is to collaborate with a strong partner in order to endorse its projects. At the same time, some Chinese module manufacturers, like Jinko Solar, have also set up business development departments with the main purpose to directly address banks in order to promote their companies and to establish trustful relationships.

\section{Differentiation through product marketing and branding}

Today's Tier 1 Chinese module manufacturing companies have adapted their strategy towards differentiation. They now focus on improving their market positioning and on creating a unique value proposition for their customers. Being bankable, but with a better cost structure in producing crystalline silicon modules, companies like Yingli, Trina and Suntech are competing on eye-level with Western module manufacturers, like SolarWorld, Q-Cells and Conergy. In order to increase their awareness and image in the European markets, Chinese manufacturers have started to intensify their marketing activities. Yingli, for instance, strongly pushed their brand through their sponsoring engagement at the FIFA World Cup 2010. Another example is Trina, who launched a branding campaign in cooperation with Renault at Formula 1. Suntech, on the other hand, seems to position itself with new products, while partnering with Enphase, a new US-based miniinverter company. And these are just some examples.

\section{Chinese module manufacturers move along a strategic path}

Interestingly, upcoming Chinese module manufacturing companies are following Tier 1 companies, like Yingli, Trina and Suntech, copying their strategic development. If, however, the newcomers in this industry, among which are also Chinese state-owned enterprises from the energy sector with huge balance sheets in their background, can develop the required internal capabilities to overcome company and country cultural barriers to achieve operational efficiency and to address global markets 
successfully, remains to be proven. Consolidation is one option, and current Tier 1 companies bet on that the most integrated companies with the best products will survive. In fact, today's Chinese module producers categorized in Tier 1 (e.g. Suntech, Trina and Yingli), Tier 2 (e.g. Jinko Solar, JA Solar and Canadian Solar) and Tier 3 (e.g. Guodian Solar, Hanergy and ChaoriSolar) companies move along a typical strategy development path as described above, characterized by the two strategic dimensions of operational efficiency and bankability ${ }^{7}$ (see Figure 8).

\subsubsection{Service providers}

\section{Service providers help to reduce project risks}

Bankability is commonly discussed with regard to projects, project developers, modules and module manufacturers. Having included these perspectives in the previous chapters, our understanding goes one step further and additionally integrates a specific group of service providers that directly contributes to project bankability. This group offers services in the field of module certification, solar radiation data provision, performance tracking and auditing. For technical auditors bankability directly depends on module characteristics and further aspects such as their interplay with inverters. Modules, as central technical components, have to guarantee for the expected performance of $\mathrm{PV}$ power plants. Thus, from this perspective bankability is based on modules' ability to secure cash flows and returns over the project lifetime. Longevity is crucial for trusted technologies, but in this regard every PV project is to a certain degree speculative due to the relatively short history of commercial photovoltaics. Here, technology certifiers and data services come into play as their information can contribute to project risk reduction. For them a new and growing market segment was created.

\section{External audits are of increasing importance}

Our interviewees reported that banks, investors and insurers increasingly demand more rigorous module test procedures. Module technologies such as thin-film or crystalline technologies, brands and manufacturers are used as basic indicators, whereas detailed company information on manufacturing technologies, quality and complaint management is more frequently requested as complementary information in course of such assessments. Another type of service provider is specialized in collecting long-term data on global solar radiation, sometimes combined with long-term performance data of selected modules or module-inverter combinations. With regard to the increasing number of manufacturers and module types, banks are more and more dependent on technical advice from such service providers and their assessments. Currently, different new services are being developed and introduced to the market, such as the PV+Test by Solarpraxis and TÜV Rheinland.

\section{Figure 8: Typical strategic development path of Chinese module manufacturers}

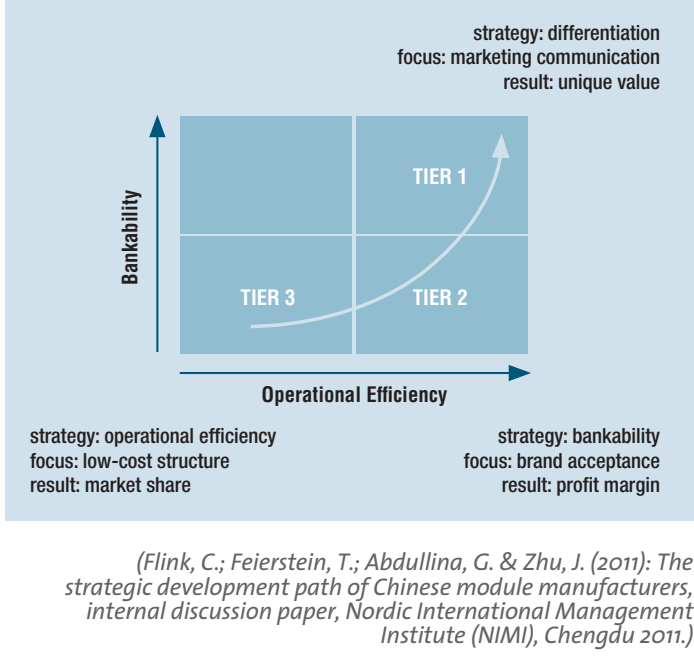




\subsection{Project bankability from a bank's perspective}

Bank lending is sensitive to policy frameworks

Bank loans for PV projects typically have a duration of around 18 years and constitute about $70 \%$ to $85 \%$ of total investments. The feed-in tariff system in Germany, with its fixed prices given by the EEG ("Erneuerbare Energien Gesetz", the German "Renewable Energy Sources Act”), allows for reliable revenue anticipation of PV projects, without the need for further assumptions. But this also means that bank lending is quite sensitive to unfavorable changes in the regulatory framework as has recently been shown in different European countries. While in Germany a recent decrease in the feed-in tariff has been predicted, in other European countries such changes occurred without any explicit prior notice and partly even had retroactive effects; examples for this include Spain and the Czech Republic. Such policy uncertainties have a high impact on the banks' willingness to finance PV projects.

\section{Banks take different stances towards new producers and modules}

Even though the share of module costs relative to total system costs has continuously decreased due to declining module prices, modules still account for about $50 \%$ of total funds needed. Besides their large impact on project costs they also constitute high technological risks. Banks therefore pay particularly strong attention to module requirements with regard to technology, certification such as from TÜV Rheinland, product guarantees etc. They are particular conservative in financing new PV module technology. Banks are only willing to finance an unknown technology if it takes up only a small part of up to $10 \%$ of a project and is combined with the use of a proven and well-established technology. In addition to these specifications, banks request certain track records from module producers, e.g. for crystalline modules track records of about 2 to $2.5 \mathrm{MW}$ over 18 to 24 months are typically required, and for thinfilm modules a performance prove of about $5 \mathrm{MW}$ over 24 months is needed. Around 2005, when the PV market was still quite immature in Germany, only a very small number of module producers were bankable. Today, the number of bankable producers has increased substantially, also including many foreign companies. Although, bank representatives agree that the large industry players, such as First Solar, Yingli, SolarWorld etc. are all bankable, the possibility to finance projects with components from smaller and relatively unknown companies seems to greatly differ among financial institutions.

\section{Banks use "white lists" to standardize and fasten processes}

Banks typically use so-called "white lists" of modules and module producers, other components and component manufacturers (e.g. inverters), and stakeholders such as project developers and EPC contractors. These lists are for internal use only and help the banks to standardize and speed up their assessment and decision processes. Project components or stakeholders that are on these lists are bankable. A comprehensive assessment process usually precedes the inclusion of components and stakeholders on 
those lists. Such lists are also subject to change if the bank witnesses negative performance of specific components or stakeholders over a certain period of time or if other components or stakeholders, not yet on the lists, fulfill the bankability requirements.

\section{Banks assess qualitative and quantitative risks} Banks finance PV projects by following a more or less standardized project assessment process (see Figure 9: Banks' assessment of PV project financing $\left.{ }^{8}\right)$. This process can be separated into four major phases or steps: (1) qualitative risk assessment; (2) quantitative risk assessment; (3) default risk assessment and rating; and (4) finance structuring. The process starts with client discussions and a first qualitative screening of the available information and the project partners such as clients, equity investors, EPCs etc. This process phase also includes a risk-return assessment based on the legal and regulatory environment, the bank's internal experience with the utilized technology and the producer, and the availability of equity capital. The bank then decides whether it wants to pursue this opportunity further or not, i.e. makes a yesno-decision. In a second step, a more detailed due diligence of the underlying fundamentals of the project, e.g. of the legal contract, licenses and permissions, and, if no previous experience exists, a detailed assessment of the client, project developer, EPC, module technology and producer, is performed. Many banks nowadays have personnel specifically dedicated to renewable energy project financing and with appropriate education in that area. They are qualified to conduct detailed assessments of technical components and their producers through visits and audits of production facilities. Other banks outsource this assessment to specialized service providers.

\section{From detailed due diligence to signed loan contract}

The due diligence also includes financial modeling of the whole project lifecycle and a stress test of this model. Under the EEG the cash flows are typically estimated for a period of 20 years. The project needs to fulfill various criteria that depend on the policy of the particular bank, such as a minimum average DSCR of between 1.1 and 1.2 and an equity ratio of $15 \%$ to $30 \%$. Banks often treat the financial modeling as an iterative process. If the project passes the stress test it can be seen as bankable and the default risk and rating is defined based on the financial model. After the internal credit committee has approved the requested loan, the client enters into a legally binding agreement with the bank, the financing structure and conditions, such as the repayment schedule and the interest rates, which depend on the rating, are fixed and the loan documents are signed.
(Lüdeke-Freund, F.; Hampl, N. \& Flink, C. (forthcoming): Bankability von Photovoltaik-Projekten, in: Böttcher, J. (ed.) Solarvorhaben - Wirtschaftliche, technische und rechtliche Aspekte, Munich: Oldenbourg.) 


\section{Conclusions and Recommendations for Future Action}

\section{Competition in module markets will further increase}

The PV industry currently experiences a shortage of political incentives, leading to a stagnation of market growth that is expected to continue throughout 2012. Additionally, more and more Chinese module manufacturers master the bankability hurdle, which further increases the competition in the module market.

\section{Bankability management to secure market position and competitive} advantage

Even though government support will continue to decrease in the years to come, at least in Europe, we expect that operational efficiency and technological advances will compensate for these shortages and give rise to further growth of the industry. Political contingencies, especially the currently renewed phase out of German nuclear power, will continue to be a major driving force. Nevertheless, PV technology producers and project developers need to carefully position their companies in order to cope with sometimes disruptive political moves while maintaining and extending competitive advantage. Here, bankability might become an essential part of business strategies. Until now bankability has been driven by banks, especially after the financial crisis in order to minimize their risks. But bankability as a criterion for PV projects, modules and module producers, project developers and other service providers has revealed a differentiation opportunity for premium brands. Related to PV modules, certificates developed in close cooperation with technical institutes and service providers are one of the key factors to provide a competitive edge. Therefore, bankability is no longer an aspect that has only to be kept in mind, but one that has to be managed actively, especially by premium brands, in order to maintain a strong market position and to keep or generate competitive advantage.

Analogies to other industries and existing management approaches Looking to other industries, one parallel might be the SDL bonus ("Systemdienstleistungsbonus") in Germany for wind turbines. Operators gain additional $0.5 \mathrm{cts} / \mathrm{kWh}$ over the first five years of operation when the wind turbine installed enables easier integration into the German power grid. To achieve this extra bonus, specific and clearly defined and certified criteria need to be achieved. This might be a good indication where active management of bankability with more tightened criteria can lead the industry. The wind industry is said to be approximately seven years ahead of the PV industry. Though, as the PV systems face similar challenges, such criteria may become reality in the mid-term. 
Another analogy is quality management. Like quality, bankability cannot be measured directly. It needs to be assessed by observing explicatory aspects such as functions, performance, longevity etc. Some of these can be measured and therefore assessed objectively, whereas others remain subject to individual perception. Bankability comprises legal, technical and economical dimensions. Addressing only one dimension will not be sufficient to achieve bankability of a project. Like it is the case for total quality management, only an active management of these dimensions as a whole will lead to a successful funding and consequently to the realization of a PV project.

\section{Active management of bankability is possible}

As described above, the stakeholders involved in a PV project have different perspectives on bankability. But all of them need to work on fulfilling the various requirements or even raise the bar for successfully taking the bankability hurdle.

The table below contains several approaches to actively manage bankability. As module producers and project developers have the highest need to achieve bankability, this table provides a summary of promising approaches to achieve and maintain bankability over time (see Table 2).

Table 2: Approaches for active bankability management by module producers and project developers

\begin{tabular}{l} 
Module producer \\
\hline Certification and testing \\
- Certification (e.g. TÜV, VDE, IEC, ISO) \\
- Product tests beyond standard \\
(e.g. 2000 h damp heat) \\
- Further voluntary tests \\
(e.g. Öko-Test, PV+Test) \\
- Participation in the development \\
of industry-wide test concepts
\end{tabular}

Downstream aspects

- Continuous focus on track record (long-term yield data)

- Mixing established and new module types

- Exploiting market bottlenecks to place new modules

- Producer roadshows and bankability events with banks and investors

\section{Others aspects}

- Continuous improvement of effectiveness and efficiency

- Manage and prove financial robustness

\section{Entry strategy}

- Develop a track record: escrow account as insurance, self-financed projects, project buyback etc.

\section{Project developer}

Relationships

- Development of relations to financiers and investors $\leftrightarrow$ roadshows and bankability events

- Development of new communication strategies

- Exclusive partnerships with premium module producers/brands

Downstream aspects

- Continuous focus on track record (project portfolio)

- Exploiting market bottlenecks to place projects

Other aspects

- OEM strategies to place new producers

\section{Entry strategy}

- Bottom-up strategy: gain reputation in the residential business field where bankability is less important to secure funding 


\section{Table of Figures}

Figure 1: Main drivers for legal, technical and economical dimensions of project bankability assessed by banks 5

Figure 2: Annual PV installations globally and in Germany [GW p.a.] 6

Figure 3: Global PV market demand development [GW p.a.] 7

Figure 4: Global PV module supply demand imbalances [GW p.a.] 8

Figure 5: Global transactions in renewable energies 9

Figure 6: Bankability - Perspectives of different project stakeholders 11

Figure 7: Merit order in PV industry - schematic 16

Figure 8: Typical strategic development path of Chinese module manufacturers 19

Figure 9: Banks' assessment of PV project financing 21 


\section{About goetzpartners}

goetzpartners is a leading independent European consulting company that combines M\&A (mergers \& acquisitions) advisory and management consulting under one roof. With this unique service offering goetzpartners advises companies along their whole value chain, thus creating sustainable value for them. The Group is represented with offices in Munich, Düsseldorf, Frankfurt, London, Madrid, Moscow, Paris, Prague, Shanghai and Zurich, and maintains international cooperation ventures.

goetzpartners Management Consultants concentrates mainly on the fields of strategy, operational excellence, and business transformation. goetzpartners Corporate Finance focuses on M\&A advisory services.

\section{Industry Line Energy/Utilities}

goetzpartners accompanies their clients on their way to renewable energy sources and the increase of efficiency, e.g. combined heat and power, decentralization and climate neutral generation from fossil fuels. Based on our integrated approach, our expertise and our deep understanding of business issues we support our clients - integrated utilities, municipalities, independent power producers, financial and infrastructure investors as well technology driven companies - in all strategic, operational and transactional topics.

\section{About COLEXON}

The international COLEXON group is a one-stop shop for solar power systems. COLEXON supplies an extensive range of solar modules and components from renowned manufacturers and complete customized photovoltaic systems as well as project-related services. The listed company is, thus, a strong partner for installers and owners of rooftop and free field areas as well as for private and institutional investors.

The Hamburg based solar power specialist has an impressive track-record with more than 1,700 successfully completed PV projects in Europe, Asia and the USA as well as an established network of high-quality manufacturers, suppliers, and service providers. Thus, COLEXON guarantees its customers excellent value for money, high-quality products, individual consulting services, and state-of-the-art technology.

Following its business model and a risk-optimized growth policy, COLEXON is well-positioned to play an important role in realizing the enormous potential of the renewable energies. 


\section{Contact}

Institute for Economy and the Environment

University of St.Gallen

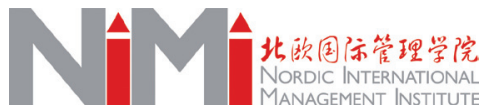

$s_{\text {extemantion }}$
Nina Hampl

Research Associate

Good Energies Chair for Management of Renewable Energies Institute for Economy and the Environment (IWÖ-HSG)

University of St. Gallen

Tigerbergstrasse 2

CH-9ooo St. Gallen

E-Mail: nina.hampl@unisg.ch

Fon: +41 - 71 - 2242746

http://goodenergies.iwoe.unisg.ch

Florian Lüdeke-Freund

Research Associate

Centre for Sustainability Management (CSM)

Leuphana Universität Lüneburg

Scharnhorststr. 1

D-21335 Lüneburg

E-Mail: luedeke@uni.leuphana.de

Fon: +49 - 4131 - $677-2522$

www.leuphana.de/csm

Dr. Christoph Flink

Vice President of Business Development

Nordic International Management Institute (NIMI)

8 Yunxing Road, Banzhuyuan Town

Xindu District, Chengdu City

Sichuan 610500 PRC

E-Mail: christoph.flink@NIMIchina.com

Fon: +86 - 13540696673

www.NIMIchina.com

Sebastian Olbert

Senior Manager

goetzpartners MANAGEMENT CONSULTANTS GmbH

Prinzregentenstrasse 56

D-80538 Munich

E-Mail: olbert@goetzpartners.com

Fon: +49 - 89 - 290725 - 593

www.goetzpartners.com

Valentin Ade

Finance Manager

COLEXON Energy AG

Grosse Elbstrasse 45

D-22767 Hamburg

E-Mail: ade@colexon.de

Fon: +49 - 40 - 28 o0 31 - 105

www.colexon.de 


\section{Disclaimer}

This report is based on public information taken from different sources, including reports, press articles, expert interviews, databases and company publications as well as project experiences. In preparing this report, the authors have relied upon and assumed, without independent verification, the accuracy and completeness of information from these public sources.

The authors point out that, if only limited, partly outdated, and/or inconsistent information was available on the topics covered in this report, they amended this information by own analysis and assumptions. The authors accept no liability whatsoever for the accurateness of these analysis or assumptions.

This report should not be used as sole source of information for any decisions related to the topics covered in this report. Any information taken from the report should be verified independently and completed by information from additional sources. This report does not carry any right of publication. 


\section{Contact}

\section{goetzpartners}

Prinzregentenstr. 56

80538 Munich, Germany

Tel.: +49-89-2907 25-503

Königsallee $60 \mathrm{~B}$

40212 Düsseldorf, Germany

Tel.: +49 - 211 - 60042 - 570

Bockenheimer Landstr. 24

60323 Frankfurt, Germany

Tel.: +49 - 69 - 2475048 - o

32 Brook Street

London $\mathrm{W}_{1} \mathrm{~K} 5 \mathrm{DL}$, UK

Tel.: +44 - $20-76477702$

Gta. Rubén Darío 3, $3^{\circ}$ Dcha.

28010 Madrid, Spain

Tel.: +34 - 91 - 7451313

Prechistensky per. 14/1 119034 Moscow, Russia

Tel.: +49 - 89 - 290725 - 257

19, Avenue George V 75008 Paris, France

Tel.: +33 - 1 - 70725513

Melantrichova 17

110 oo Prague 1, Czech Republic

Tel.: $+420-221632451$

Schwerzistrasse 6

8807 Freienbach/Zurich, Switzerland

Tel.: +41 - 55 - 4102294

Unit 1610, No. 336 Middle Xizang Road, 200001 Shanghai, P.R.China

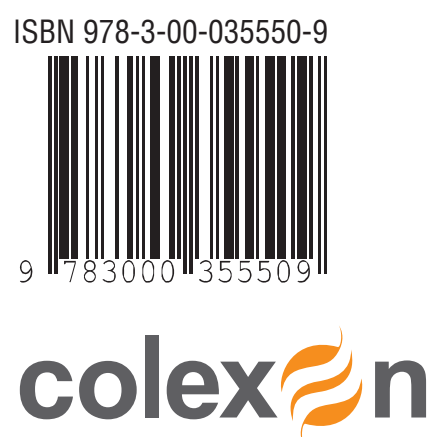

